\section{Wax Casts}

Candles, cosmetics, and carbon paper; industrial dies and death masks; statues and sorcery: These are just some of the ways people have found to put wax to use over the centuries. Its ubiquity can be attributed to the fact that it fills a void in the materials world: It is one substance that can easily be worked in both its solid and liquid forms. In early human history, metals smelted from ores could be formed by forging, but not into any intricate shapes; clays could be molded and fired into pottery, but further shaping was difficult after that point. A plastic material that could be worked and reworked at ambient or moderately elevated temperatures was essential to the progress of people's attempt to shape the objects in their environment into useful and beautiful forms.

Natural waxes occur as the result of biological processes in animals or plants. The honey bee (Apis mellifica) constructs the honeycomb cells of its hive by secreting flakes of wax from eight glands on the underside of its abdomen. When harvested, the honeycomb is melted and filtered to produce pure beeswax. The Chinese insect Ceroplastes ceriferus deposits its hard, crystalline wax on the branches of certain trees, then suffers the indignity of being boiled in water to extract the wax still inside its body. In the plant kingdom, cuticle waxes secreted as protective coatings on the leaves help to retain moisture in arid regions. Carnauba wax from the carnauba palm in Brazil, and candelilla wax found on the candelilla shrubs of Mexico and Texas are just two examples of this type.

The natural waxes, whether animal or vegetable in origin, share similar properties: They melt at moderate temperatures of $35-100^{\circ} \mathrm{C}$, and cool into hard, glossy finishes. Chemically they are composed mostly of high molecular weight fatty acids, straight-chain alcohols containing an even number of carbon atoms greater than 12 , and saturated hydrocarbons.

While the discovery and use of wax materials is necessarily lost in the obscuring clouds of history, it is generally agreed that either beeswax or Chinese insect wax was first used for practical purposes. Predictably, the Egyptians played a large role in the early development of wax materials. Beeswax was used to seal openings in the body during the mummification process, and the emergence of written hieroglyphic forms for communication was carried out largely on wax tablets poured into shallow wooden molds. These could be erased by rubbing or renewed by pouring fresh molten wax, and were infinitely easier to use than stone tablets. The earliest attempts at oil painting involved the "encaustic" method developed by the Egyptians, in which pigments were ground into beeswax and applied to a surface by a heated spatula.

But the most important development in wax technology occurred in the third millennium BC during the Bronze Age: the simultaneous development on several continents of the Cire Perdue, or "lost wax" casting process. With small refinements in technique to control the quality and sizing of the finished goods, this method of casting is with us to this day.

Egyptians played a large role
in the early development of
wax materials...the emergence
of written hieroglyphic forms
for communication was
carried out largely on wax
tablets poured into shallow
wooden molds.

While initially the technique was used for making small, solid objects (such as jewelry), the technique is famous for producing the life-size bronze statues of the Renaissance. Casting a large object requires careful attention to detail and refinement of technique. First, a core of disposable material, typically plaster, is formed to approximate the size and shape of the statue. Next, wax is melted over the surface of this core in a layer whose thickness determines the ultimate wall thickness of the hollow bronze statue. The wax is then carved by the artist into the likeness of the person or object being depicted. Small metal rods, called chaplets, attached to the core, stick through the wax form in strategic places to keep the core from shifting in the mold when the wax is removed; wax rods are also inserted to provide holes for the molten metal to enter and entrapped air to escape. For a large and intricate statue, the mold is typically made in sections, with the arms molded separately. The wax form is covered with several thin layers of wet clay or a clay/plaster mixture, and allowed to solidify and dry. When the composite mold and core is heated, the wax runs out, leaving the clay mold with the plaster core suspended from the chaplets with a gap in between where the wax used to be. Molten bronze is poured into this gap. When the bronze cools, the mold is chipped off and the core raked out, leaving a hollow statue of durable metal in place of the fragile wax model. These bronze statues have survived the centuries without the loss of limbs common in the marble statues of ancient times.

In the more mystical realms, the magical power of beeswax was invoked by ancient civilizations in Egypt, Babylonia, and India using what would be called "voodoo" practices today: A figurine of the person to be harmed was fashioned from wax, then subjected to various tortures (insertion of needles being typical). The living person ostensibly felt all the pain being inflicted on the wax replica. In funeral rites, wax death masks of ancestors frequently accompanied the newly dead on their journey to the grave.

On the humane side, the Mayans performed healing rituals by forming a wax model of the injured body part, praying over it, then burning or burying it. The injury or illness would seemingly be transferred from the sick person to the model, and the person would be healed.

In the Middle Ages the Roman Catholic Church required candles to be made entirely of beeswax due to the supposed purity, industry, and chastity of the hardworking honey bee. As a result, a working apiary was part of every monastery in the empire. Craft guilds were formed in the 1300 s to support the manufacture of candles, with the Worshipful Company of Waxchandlers (founded in London in 1358) fighting for market share with those less enlightened tallow candle makers across town.

Wax was a relatively rare material throughout most of history due to people's reliance on the biological processes of plants and animals for production. Indeed, in the 16th century the price of beeswax was so high that merchants frequently mixed it with lesser varieties to maximize their profit. This prompted Queen Elizabeth to pass an "Acte for the true melting, making and working of Waxe" in 1580 to punish offenders.

In Berne, Switzerland, circa 1760, a physician named Curtius gained fame for the wax models of internal organs he fashioned for his anatomical studies. As his skills developed, he abandoned medicine and switched to wax portraiture as a more enjoyable and profitable line of work, establishing a studio in Paris called the Salon de Cire that became the preferred gathering place for noted intellectuals of the time.

Curtius used a circuitous route to produce his wax portraits. First, he applied 
plaster to the subject's face and allowed it to harden while the person breathed through quills inserted in the nostrils. Next, he removed the plaster casting and pressed clay into the mask. Detailed features were then sculpted into the clay following precise measurements that Curtius had taken from the subject's face. When he was satisfied with the likeness in clay, he would take a plaster casting of the clay form, and this would serve as the mold for the final wax bust. Coloring of the features and insertion of hair finished the job.

A talented apprentice (possibly his niece) named Marie Gresholtz (later Madame Tussaud) began studying under Curtius at the age of six; by the time she was 17 in 1778 she had sculpted wax portraits of Benjamin Franklin, Voltaire, and Jean Jacques Rousseau. At 20, Gresholtz was appointed to the position of art tutor to the royal court of Louis XVI and Marie Antoinette at Versailles, where she produced wax statues of the royal family. When revolution struck in Paris in 1789 she was forced at the point of a sword to help the revolutionary cause by creating wax death masks from the newly severed heads of the victims of the guillotine, often her friends. Having sculpted Marie
Antoinette's portrait from life in 1789 , she fashioned it from death only four years later.

In 1867, about a decade after the first oil well was drilled, dependence on biological processes for wax supplies ended with the first commercial production of paraffin wax. Paraffin is a mixture of solid, straight chain hydrocarbons that separates from petroleum on cooling, and so can be obtained in large quantities. It is a hard, white material, with a melting point between $48^{\circ} \mathrm{C}$ and $66^{\circ} \mathrm{C}$, which makes it an excellent material for candles, coatings, polishes, and electrical insulating devices. In 1887, Thomas Edison formed a hollow cylinder out of wax with walls 0.25 -in thick $(6.4 \mathrm{~mm})$ to replace the tinfoil recording medium he had patented for his first phonograph. Using a sapphire needle that cut one-thousandth of an inch deep into the wax in response to sound vibrations, Edison vastly improved the quality of his recording device.

The combination of the lost wax process with an abundant source of paraffin wax (and, later, synthetic waxes) eventually provided a valuable tool for industry. Developed by engineers at the HaynesStellite Company of Kokomo, Indiana, starting in 1937, an "investment casting" process produced a die that could be used repeatedly to manufacture identical parts for guns, cars, planes, and other machinery. After much experimentation, mass production of replaceable parts was realized. In addition, intricate parts (such as jet turbine blades) made of new alloys that could not be forged or machined were easily formed using wax as the shaping material and the lost wax (investment casting) process as the method.

Not bad for a Bronze-age invention.

TIM PALUCKA

For FurTHER READING: Nelson S. Knaggs, Adventures in Man's First Plastic: The Romance of Natural Waxes (Reinhold Publishing Corporation, New York, 1947); Albin H. Warth, The Chemistry and Technology of Waxes (Reinhold Publishing Corporation, New York, 1947); Carol C. Mattusch, Classical Bronzes: The Art and Craft of Greek and Roman Statuary (Cornell University Press, Ithaca and London, 1996). Established in London in 1835, Madame Tussaud's wax museum is located at Marylebone Rd, NW1; tel. 44-71-935-6861.

\section{...for information available via the internet that is of interest to the Materials Research Community...}

\section{www.mrs.org/ gateway/}

Materials Information

includes

$\nabla$ Patents- Intellectual Property N etwork from IBM

$\checkmark$ A tomic and Plasma physics databases from the W eizmann Institute

$\checkmark$ EN G netBASE-Engineering Database 0 nline

$\checkmark$ 3-D M olecular Structures Library at N ew York University 